\title{
Maxakalí Nasality and Field Recording with Earbud Microphony
}

\section{Nasalidade no Maxakalí e gravação em campo com microfonia de fone de ouvido}

\author{
Andrew Ira Nevins \\ Universidade Federal do Rio de Janeiro, Rio de Janeiro, Rio de Janeiro / Brasil \\ a.nevins@ucl.ac.uk \\ Mário André Coelho da Silva \\ Universidade Federal de Minas Gerais, Belo Horizonte, Minas Gerais / Brasil \\ mario.andrecs@gmail.com
}

\begin{abstract}
The challenges in verifying vowel nasalization acoustically are well-known, and for this reason many researchers have opted for the use of nasal airflow masks. Such equipment, however, is not always affordable for recordings or projects conducted in the field. In the present article, we apply the recently developed technology of earbud recordings in Stewart \& Kohlberger (2017) to the study of nasality in Maxakalí as a new method in experimental fieldwork phonology. This language has several phenomena related to nasality such as nasal spreading, prenasalization at the beginning of words, and glottal transparency in morphologicallyalternating 'long forms'. One goal in using methodology with affordable equipment is to make it easier to generate a visual representation of the timing of the nasal profile of a word, thereby yielding possibilities for experimental linguistics to show increased integration with language description and pedagogy.
\end{abstract}

Keywords: nasal harmony; prenasalized stops; loanword phonology; Maxakalí; field recording. 
Resumo: As dificuldades em se verificar acusticamente a nasalização de vogais são bem conhecidas e por isso diversos pesquisadores optam por usar máscaras de fluxo nasal. Porém, esse tipo de equipamento nem sempre é prático para gravações em campo. No presente estudo, foi aplicada a tecnologia recentemente desenvolvida de gravação com fones de ouvido apresentada em Stewart e Kohlberger (2017), com o intuito de estudar a nasalidade no Maxakalí e esse processo de gravação como um novo método de fonologia experimental em campo. A língua Maxakalí conta com diversos fenômenos ligados à nasalidade como, por exemplo, espraiamento de nasalidade, pré-nasalização em início de palavra, entre outros. Um objetivo ao usar uma metodologia com equipamentos de baixo custo é facilitar a geração de uma representação visual do perfil nasal de uma palavra, produzindo possibilidades para a linguística experimental mostrar uma integração maior com a pedagogia de língua.

Palavras-chave: fonologia de empréstimos; gravação em campo; harmonia nasal; Maxakalí; oclusivas pré-nasalizadas.

Recebido em: 10 de dezembro de 2016.

Aprovado em: 3 de abril de 2017.

\section{Background on Maxakalí and difficulties of nasality in Acoustic Analysis}

\subsection{An overview of Maxakalí phonology}

Maxakalí is an indigenous Brazilian language spoken in Minas Gerais state by about 2,000 people. It forms part of the Macro-Jê stock and it is the only extant language within its branch. Maxakalí is well known in the phonological literature for a number of properties such as the lack of any phonological liquids and the prevocalization of all its eight consonants in coda position (GUDSCHINSKY; POPOVICH; POPOVICH, 1970; WETZELS, 1993; WETZELS; SLUYTERS, 1995; ARAÚJO, 2000; SILVA 2015). The table below shows the language's consonantal inventory, as well as the prevowels resulting from coda lenition (or prevocalization): 


\begin{tabular}{|c|c|c|c|c|c|}
\hline & labial & dental & palatal & velar & glottal \\
\hline \multirow[t]{2}{*}{ voiceless stop } & $\mathrm{p}$ & $\mathrm{t}$ & $\mathrm{c}$ & $\mathrm{k}$ & $?$ \\
\hline & {$[\gamma]$} & [ə] & [j] & [ய] & \\
\hline \multirow[t]{2}{*}{ voiced / nasal stop } & $\mathrm{b} / \mathrm{m}$ & $\mathrm{d} / \mathrm{n}$ & $\mathrm{J} / \mathrm{n}$ & $g / n$ & \\
\hline & {$[\tilde{\gamma}]$} & [ə̃日] & [j] & [ü] & \\
\hline fricative & & & & & $\mathrm{h}$ \\
\hline
\end{tabular}

An important allophonic process in Maxakalí is the one involving voiced and nasal stops: nasal stops always precede nasal vowels and voiced stops most of the times precede oral vowels. The two instances where voiced stops precede nasal vowels are in some verbs with the [-nãy] suffix (further discussed in Section 3.5) and in loanwords. It is also important to know that the coda position always agrees in nasality with the syllable nucleus, so the consonant in this position is underspecified for nasality (SILVA; NEVINS, 2015). As can be seen from the Table above, glottals do not undergo lenition, as they never occur in coda position (except for some loanwords). Therefore, both $/ \mathrm{P} /$ and $/ \mathrm{h} / \mathrm{do}$ not have a prevocalized allophone.

There is a long discussion in the literature about the underlying nature of voiced $\sim$ nasal stops. Gudschinsky, Popovich \& Popovich (1970) contend that Maxakalí has nasal stops and a contrast between oral and nasal vowels, such that nasals become oral before oral vowels (as represented in Popovich's orthography). Rodrigues (1981) claims that, except for a few instances, there are just oral stops and oral vowels in the language and that by the means of a rule, codas become nasalized and then spread nasality to the segments to their left. Araújo (2000) argues that there are nasal consonants and oral vowels only, and that nasal coda consonants are responsible for spreading nasality to other segments. Finally, Wetzels (2009) postulates that there are oral consonants only and both nasal and oral vowels. According to him, stressed nasal vowels are responsible for spreading nasality to other segments. In this paper, we follow Wetzels' hypothesis, as Gudschinsky, Popovich \& Popovich's is typologically unnatural, Rodrigues' cannot explain why words without a coda may be nasal (then treating them as exceptions) and Araújo's is not adequate to explain why epenthetic vowels in $\mathrm{CCV} C$ words are nasal and not oral. 
The syllabic structure of Maxakalí, according to Gudschinsky, Popovich \& Popovich (1970), consists of a maximum of CVC, in which any consonant can be placed in onset position and, as said before, all consonants but the glottals can occupy coda position. Silva (2016) argues that the maximum syllable is, in fact CCVC - but this larger syllable type is restricted to cases in which the first onset consonant must be a non-coronal (labial or velar) and the second onset position must be filled in almost every case by a coronal. This structure corresponds to Proto Macro-Jê ${ }^{*} \mathrm{CrVC}$ with a Proto-Maxakalí change of $*_{\mathrm{r}}>\mathrm{d}>\mathrm{t}$.

Lexical stress falls on the last syllable of the word, but because of some interactions between the nuclear vowel and the coda consonant, it can be located in the penultimate syllable. This interaction has to do with the insertion of a glide, which can be predicted by the vowel and the prevowel resulting from consonant lenition. The table below shows which vowels interact with which coda consonant and some examples:

\begin{tabular}{|c|c|c|}
\hline & dental & palatal \\
\hline /i/ & [j] /cit/> ['tcijə] 'thread' & - \\
\hline$/ \mathrm{a} /$ & [щ] /tat/ > ['tauə] 'get (uncount.)' & - \\
\hline /ít & [ய] /-kit/ > ['ki்)] 'louse' & [ü] /cic/ > ['tciulu ] 'leaf' \\
\hline /o/ & [w] /kot/ > ['kuwə] 'tobacco' & [w] /poc/ > ['powi] 'arrow' \\
\hline
\end{tabular}

The same phenomenon also can be observed with nasal vowels, as

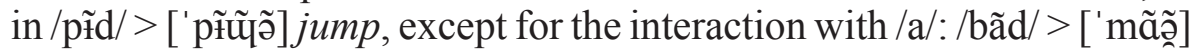
and not *['mãũ̃ $]$ shoot. The final consonant, even though uncommon, can sometimes be heard in this context: ['kiuə] ['kiuət]. For further discussion, see Wetzels (1993) and Wetzels \& Sluyters (1995).

Some other phonological phenomena (besides nasal spreading, which, as mentioned, will be discussed in Section 3.5) found in Maxakalí regarding nasality are the prenasalization of consonants, left-edge nasality, glottal transparency and nasality in loanwords. The first of these, which will be presented in section 3.2, is found in words beginning with voiced stops, both in native and loanwords, although not in medial position. ${ }^{1}$

\footnotetext{
${ }^{1}$ It seems that compound words where the second element begins with a voiced stop have some degree of variation (e.g.: / kik + bac/ > [kэщ' baj] [kэu' 'mbaj] 'turtle'). The pattern in compounds, however, awaits more extensive confirmation with recordings of the type we explore in the text (and a range of compound types).
} 
(1) /bai/ > ['"ba'i] [ba'i] 'to be good'

(2) $/ \mathrm{kibik} />$ [ki' biul], but *[ki' 'mbiul] 'to be bad'

Somewhat related to this, there is left-edge nasality (section 3.1) in which vowels are nasalized from left to right, an apparent exception to the better understood right-edge nasality. There are just a few native words which fail to nasalize in this onsetless, word-initial context, and many loanwords have been adapted with nasal vowel even when in the source language there is no nasality, such as in (3):

(3) Portuguese [oli'verə] > [õnĩ' beə] 'Oliveira' (surname)

In section 3.3, we present evidence for glottal transparency. In Maxakalí, there are some nouns and verbs which alternate between short and long forms, according to syntactic and/or prosodic context. These words have a short form CVC and a long form CVHVC, in which the $\mathrm{H}$ corresponds to a glottal consonant and both Vs have the same phonetic value. We will argue that long forms are derived from the short ones, and that the glottal consonant cannot block nasal spreading, thus remaining transparent for nasality.

In section 3.4, we discuss nasality in loanwords from Portuguese. Some of the phenomena discussed above also apply to loanwords, but there are some exceptions, such as variation in nasal spreading. An example in which nasality varies is shown below:

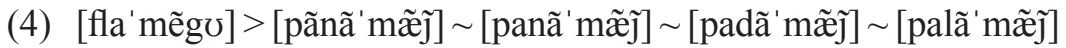
'Flamengo' (soccer team)

In short, Maxakalí has prenasalization, coda nasalization, and nasal harmony within the syllable, between nucleus and rime, between rime and onset, and from syllable-to-syllable. Each of these processes show potential locality effects, based on factors such as loanword status, morphological restrictions, and intervening glottals. Development of theoretical models of the underlying forms and the nature of these processes therefore depends on a firm empirical basis for knowing the surface forms themselves. 


\subsection{Prior tecnhiques for studying nasality}

As the discussion above reveals, Maxakalí is a rich domain for the study of nasality, and many of its details present interesting challenges for theoretical models. Nonetheless, as is widely acknowledged, instrumental verification of nasality is not entirely straightforward. The literature contains varying suggestions for acoustic landmarks of nasality (such as CHEN, 1996; STYLER, 2015), but these are largely developed for vowel nasality, and as discussed above, many of the phenomena of interest in Maxakalí involve consonants as well. Measurements using nasal airflow masks (SHOSTED, 2006; DEMOLIN, 2011) are extremely informative, but such equipment is often expensive for researchers based in the 'Global South'. To take an example that is all-too common, there are few if any Brazilian linguistics researchers or postgraduate students who have the budgetary support for equipment of this kind. Even costs aside, the analytic techniques involved in calibration and processing of aerodynamic data require technical training that may not even be available in all regions where these languages are bring spoken and studied. And bringing a range of demographically diverse participants from a village setting into an urban laboratory hundreds of kilometers away is also not always practical, not only for financial but also for cultural reasons. On the other hand, earbuds are inexpensive and portable, and familiar to participants who have seen them with mobile phones, and we have found that they are welcome in virtually anyone's home in the village, and are perceived as fairly discreet even in scenarios where the recording takes place among a range of extended family members of varying ages. Earbud recordings and the corresponding visualization can be informative in confirming or disconfirming impressionistic percepts of nasalization by fieldworkers and language teachers even with a limited background in acoustic phonetics. The main output of this technique is nasalance, the relative prominence of the amplitude of nasality versus orality, originally developed in Fletcher, Sooudi \& Frost (1974) for clinical purposes, which can be graphed temporally with a corresponding transcription to show the details of timing of velar opening.

Nasalance was originally measured using an acoustic 'baffle', a plate separating the nostrils from the upper lip. However, the method we use follows Stewart \& Kohlberger (2017)'s proposal of earbuds as a method of field recording, with no baffle in place. Prior acoustic studies using this method include Montagu \& Amelot (2005) and Audibert \& 
Amelot (2011). Stewart \& Kohlberger bring to the fore the usefulness of this technique in studying phenomena such as nasal harmony, which, given their geographic distribution, tend to cluster in regions within the Global South, where nearby training resources call for a more intuitive method for instantly displaying the action of the velum in controlling nasality. This is an invaluable exercise when working with native speakers to discuss oral/nasal contrasts as they relate to, say, orthographic marking (i.e. should prenasalization be marked? Well, we now have very easy methods to see how consistently it is produced - and whether the variation found is phonologically-predictable, lexically specific, or negligible, and thus making corresponding orthographic decisions). Given that all of the scripts for their paper are now openly available on the Language Documentation and Conservation journal site accompanying Stewart \& Kohlberger (2017)'s publication, and that all of our recordings reported in this study are available with their corresponding segmented textgrids, any reader of this paper can analyze or visualize the entirety of the data we have collected. We strictly follow the method outlined in Stewart \& Kohlberger (2017) for using earbuds as microphones to record a nasal track, alongside the simultaneous recording of an oral track and subsequent software post-processing as a means of representing nasal airflow, and focused our efforts on an experimental and demographic design and method that would allow us to collect a body of data and a set of illustrative analyses for well-known unresolved descriptive questions, the resolution of which leads itself to more well-informed theoretical and orthographic decisions.

\section{The present study}

\subsection{Equipment and recording procedure}

For data collection we used a Zoom h4n recorder, as it has two microphone inputs. The Zoom $\mathrm{h} 4 \mathrm{n}$ recorder has the advantage of being able to record two tracks simultaneously, although two recorders (one for recording oral track and the other for nasal one) would be equally suitable for data collection. The most important thing is that these tracks be recorded separately.

In one of the inputs, we connected a wired CSR Pro 2.1 Microphone for the oral track recording. In the other input we plugged 
Samsung earbuds with silicon tips (the price of a single pair, as of the time of writing, is around $50 \mathrm{BRL}$ ). A P2 x P10 adaptor was needed as the earbuds have a P2 connection, while the recorder has a P10/XLR input. The earbuds should preferably be of low impedance $(\sim 27 \mathrm{ohms})$ :

Because earphones work on the same basic principle as microphones (i.e. a diaphragm vibrates when agitated by a medium and a copper coil around a magnet creates an electromagnetic field which interprets the signal), earbuds function as small microphones when attached to the input jack of a recording device. (STEWART; KOHLBERGER, 2017, p. 52).

With both microphone (for the oral track) and earbuds (for the nasal track) connected to the recorder, the participant was asked to hold the earbuds below each nostril, so nasal flow could be recorded. The oral track was recorded with the microphone, which was held by the researchers. At first, we tried a wireless mic on the oral track, so no one would have to hold the microphone. However, its wireless transmission generated low-level background noise that was picked up by the nasal earbuds, so we opted for a wired microphone. The downside of this wired microphone setting was that the recording procedure thereby needed one person to hold the microphone for the participant (whose own hands were busy with the two earbuds), and this time we did not take a tripod to the field.

Participants were asked for the translations of the words collected for this study, while holding the earbuds below their nostrils. The wordlist was randomized for each participant, in order to avoid any bias. The wordlist and the translation of its items can be found in Appendix A. As the answers in terms of translation equivalents were open, sometimes participants did not give the expected ones. For example, when asked for 'doggy' (Pt. cachorrinho), the expected Maxakali elicitation was for kokexnãg (dog-DIM), but a few participants said things like kokex kutok (dog-offspring) or kokex kutĩynãg (little dog). Thus not every participant provided the same set of tokens as every other.

\subsection{Post-processing}

Recordings were amplified at $12 \mathrm{~dB}$ with Zoom's built in amplifier on the nasal channels. We first selected the words of interest in Praat 
in both tracks in parallel using the Group checkbox, and then made a textgrid based on the oral track, segmenting each recorded token into a phonetic form with the SAMPA transcription. We then used Praat to generate Intensity and Sound textfiles for the words of interest. All of these sound files can be found in the accompanying materials to this article, in the format axõk-oral-PM and axõk-nasal-PM, where these are the recording from the oral and nasal tracks, respectively, alongside a corresponding textgrid of the form ãxok-PM.textgrid (where PM, in this case, is a code for this particular Maxakali speaker). By superimposing the two intensity curves and using Stewart \& Kohlberger's (2017) script (available at http://nflrc.hawaii.edu/ldc/ as of April 2017) to normalize the two tracks using intensity in decibels, one can generate the visualized superimposed curves shown in the discussion below.

\subsection{Demographics}

We recorded 5 female speakers (DM, EM, MM, MSM, and SM) and 6 male speakers (GM, IM, IZM, PM, RM \& TM), all of them living in Aldeia Verde (one of the four Maxakalí villages), located near the town of Ladainha, Minas Gerais state. There are about 350 inhabitants in this village. People in virtually all households but one speak only Maxakalí to each other. Most people in this village have at least some understanding of Portuguese, in a continuum of competence: some people are fluent in both Maxakalí and Portuguese on the one hand, but on the other hand some inhabitants (mainly women) can understand but do not produce full sentences in Portuguese.

In terms of age, there were 6 younger speakers (DM, EM, GM, IM, and RM), with apparent age spanning from 15 to 30 years old, 4 adult speakers (MSM, SM, IZM, and PM) from approximately 30 to 50 years old, and 1 elder speaker (TM) more than 80 years old.

\section{Empirical issues}

In the following subsections, we highlight five empirical issues that have been the matter of some debate within the description of Maxakalí phonology, and which receive a more concrete empirical picture given the ability to document nasality and clearly represent it with normalised intensity curves aligned with the segmental transcription of the accompanying token. 


\subsection{Left-edge nasality}

A phenonemon noted in Silva \& Nevins (2015), independently noted in the transcriptions in Popovich \& Popovich (2005), is the spontaneous nasalization of vowel-initial loanwords that have neither nasal vowels nor nasal consonants present in the source word. For example, açúcar, when loaned into Maxakalí, is [ã'tou], with the surprising appearance of a nasal vowel. There are very few morphemes in Maxakalí that begin with oral vowels (e.g. negation $a$-, interrogative $o k$-), and only a handful of words to our knowledge, e.g. onop 'bee', that are not a suffix, onomatopoeic, or a loanword. What this overwhelming distribution of nasal vowels at the left edge of Maxakalí, even spontaneously so in loanwords, suggests, is that the 'default' specification at the left edge of Maxakalí words is nasality. This line of reasoning follows an observation in Rodrigues (1986) (further developed in Sândalo \& Abaurre (2010) and Fujimura (2010)) that in a great deal of lowlands South American languages, the default resting position of the articulators beginning from silence is to have the velum lowered and to produce nasalization, unless otherwise interrupted by an explicit lexical [-nasal] specification. However, the phenomenon in itself remains surprising, and therefore is exactly a domain in which instrumental verification is of use. Consider, therefore, the following Intensity comparisons. The transcription accompanying the segmentation is in X-Sampa (see Appendix B for correspondences with the IPA). In all figures throughout this paper, nasal intensity is plotted with a solid line, and oral intensity with a dotted line.

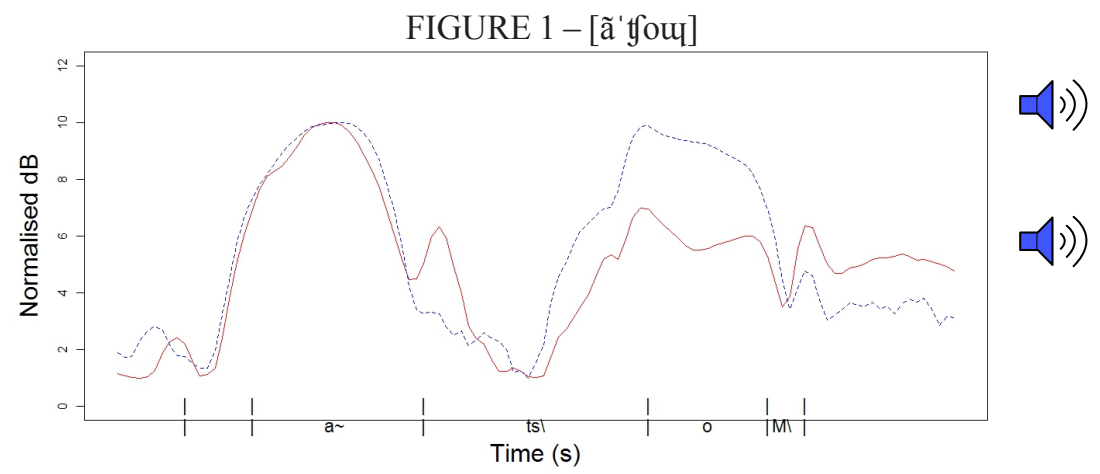


This example was elicited with young female speaker EM; similar curves were found for the other speakers, and in the is paper, we generally include one representative visualization per word token of interest, for reasons of space. As can be clearly seen in the diagram, the first vowel is nasal, with an equal intensity of oral (dotted) and nasal (solid) tracks, which extends into the initial portion of the affricate. Nasality does not reach this level any later within the word, and the second vowel is clearly more oral than the first. This example thus confirms a degree of nasalization on the initial vowel, in concord with previous descriptions.

A second loanword noted to exhibit this phenomenon results from the adaptation of espelho 'mirror', adapted into Maxakalí as [?ĩ̄' pæjç], shown below.

FIGURE 2 - [?ĩj' pæjç]

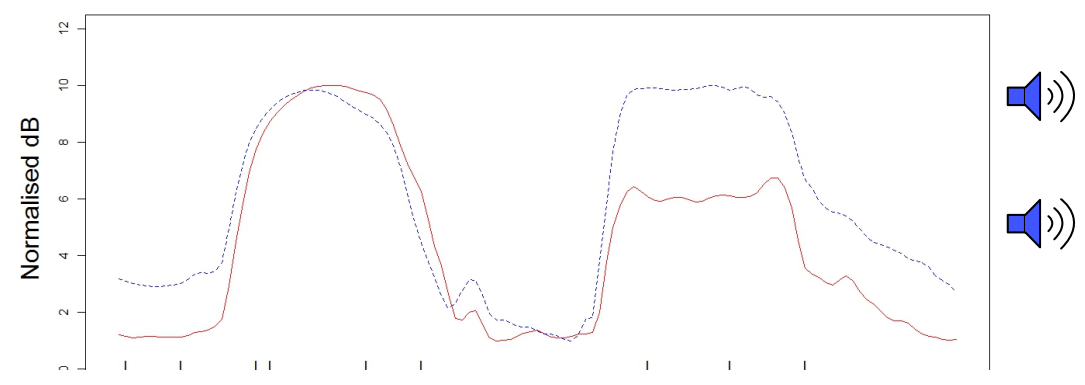

This example, from young male speaker IM, demonstrates a profile parallel to that of [ã' tou]: the first vowel shows an equal nasal and oral intensity, extending into the offglide, and then no longer present during the closure and release portion of the following stop, nor in the second vowel of the word. The intensity curves therefore again confirm the auditory transcription of spontaneous nasalization of the initial vowel.

In a third example, however, elicited with the loanword espora 'spur', its adaptation into Maxakalí did not show this initial nasalization [ij'poə]. This token, recorded with adult male speaker GM, does not show nasalization. 
FIGURE 3 - [ij' poəa $]$

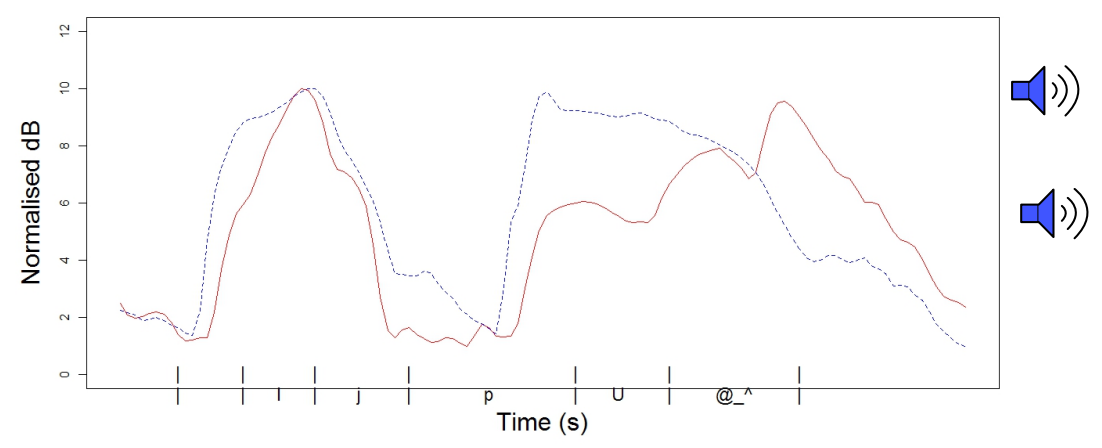

In this example, in contrast with the other two presented above, nasalization never reaches the same level of intensity as the oral profile in the initial vowel. We may thus conclude that initial nasalization did not take place with this token. There are a few possible explanations for its absence here. The first is the fact that this particular token refers to spurs (as found on a cowboy's boots), which may be a word of less familiarity and lesser usage to the speaker in question. The second is that this particular speaker has a higher degree of bilingualism, using Portuguese in his daily work. Comparison of the same token with older speakers, or of different tokens with the same speaker, could potentially arbitrate between these explanatory paths.

To conclude this subsection, we have demonstrated the utility of nasality measurements in bolstering the empirical support for the description of spontaneous initial nasalization. As such, the enterprise of continuing its theoretical explanation, in terms of a potential articulatory 'default' setting of left-edge nasalization, along the lines of Rodrigues (1986), may be further elaborated.

\subsection{Prenasalization of stops}

As has been documented throughout the literature on Maxakalí, from Gudschinsky, Popovich \& Popovich (1970) onwards, the language has the presence of prenasalized stops such as $\left[{ }^{\mathrm{n}} \mathrm{d}\right]$ word-initially. Prenasalization of voiced stops is a pervasive feature throughout lowlands South American languages, although with different potential underlying causes. For example, as discussed by Wetzels \& Nevins 
(2016), prenasalization may reflect 'hypervoicing', the mechanism discussed by Iverson \& Salmons (1996) and Piñeros (2003), in which lowering the velum during the initial closure portion of a voiced stop allows maintenance of the pressure differential between subglottal and supraglottal regions that enables continued vibration of the vocal folds.

Differently from Southern Jê languages such as Kaingang, Maxakalí does not have oral-nasal contour segments [ $\left.{ }^{\mathrm{d}} \mathrm{n}\right]$ or circumoralized stops $\left[{ }^{\mathrm{d}} \mathrm{n}^{\mathrm{d}}\right]$, which Wetzels \& Nevins (2016) argue is the hallmark of a different underlying force, namely one to shield neighboring oral vowels from potential coarticulatory contamination by an adjacent nasal consonant. As such, Maxakalís prenasalized stops reflect the articulatory motivation of 'venting' an underlying voiced stop, and therefore documenting the existence of the nasal realization is an important aspect of the description to confirm. We include here three tokens: one is a Maxakalí noun, the second a loanword from Portuguese, and the third, a Maxakalí verb.

The first token presented here is [ ${ }^{\mathrm{n}} \mathrm{da} \mathrm{a}^{\mathrm{rj}}$ ], 'clay pot', as recorded with adult male speaker PM.

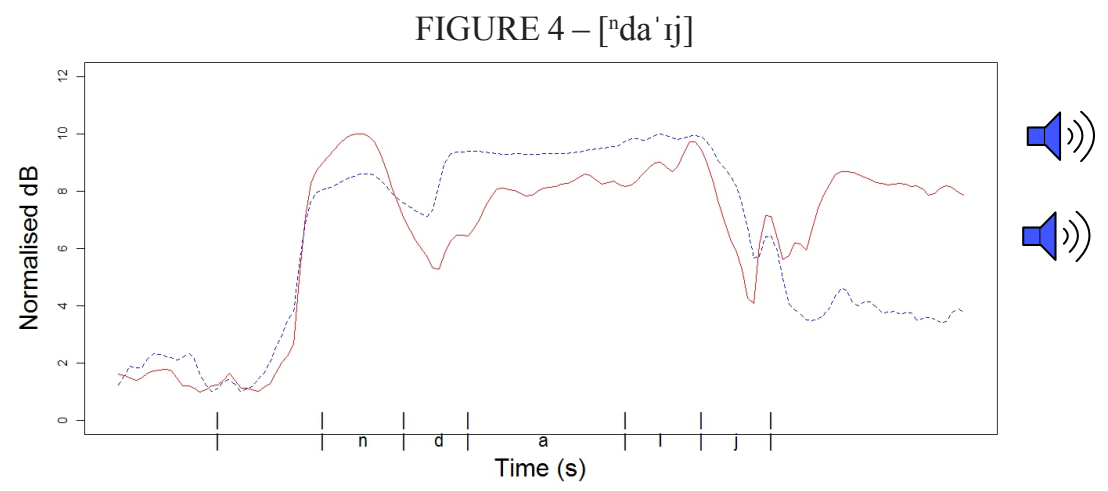

This example shows a clear prenasalization phase preceding the closure and release portion of the voiced stop that follows it. The velum remains raised for the remainder of the word until after the final consonant, at which point in the nasal track may simply reflect an outward breath and/or a return to the resting state of the articulators. From tokens such as this one, we can conclude that Maxakalí possesses prenasalization, the timing profile of which is easily enabled by the earbud recording method. 
The second token chosen for inspection is the loanword ["ga' har], from the Portuguese garrafa 'bottle'. The presence of prenasalization in this example bolsters the explanation of this phenomenon as reflecting hypervoicing of an underlying oral voiced stop, as the source word is clearly non-nasal.

FIGURE $5-\left[{ }^{\mathrm{g} g a}\right.$ ' har $]$

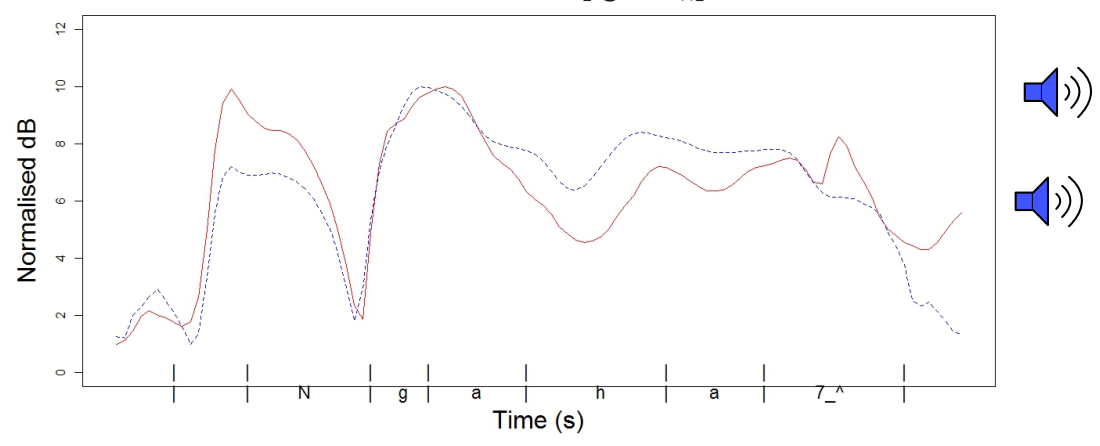

In this example, recorded with elderly female speaker MSM, there is a clear nasal portion, which in fact extends all the way into the beginning of the vowel. This speaker, therefore, has lowered the velum to achieve venting, and shows delayed closure to a purely oral airflow.

The final example of prenasalization considered here is with the verb [mba'i] 'to be good'. Although this may be considered an adjective, as discussed by Campos (2009), it takes the same agreement prefixes as verbs. In fact, these agreement prefixes often inhibit (or bleed) the realization of prenasalization of the underlying voiced stop, as this prenasalization only reliably takes place in absolute word-initial position. ${ }^{2}$ However, in this particular token, adult male speaker IZM does not produce it with the person prefix, which is common given that this particular lexical item can be used to mean something like "okay", without a referential subject.

${ }^{2}$ Campos (2009, p. 18-19) contends that this prenasalization in verbs is one of the realizations of the third person prefix. However, if the prenasalization were a form of the third person prefix, it would be hard to explain why alienable nouns (which cannot occur with such prefixes) also show prenasalization in the same contexts. 
FIGURE $6-\left[{ }^{\mathrm{m}} \mathrm{ba}\right.$ 'i $]$

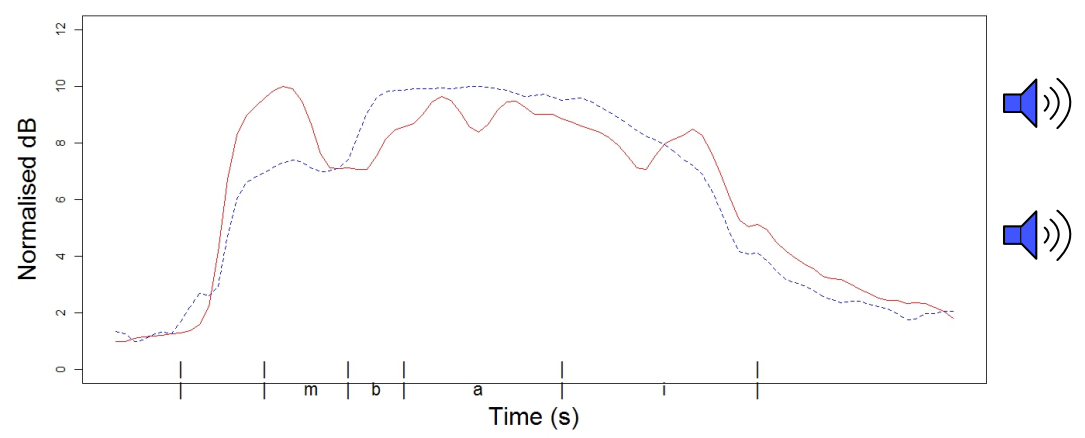

Much like the realization of [ ${ }^{\mathrm{n}} \mathrm{da}$ ' $\left.\mathrm{rj}\right]$ above, this example shows a clear distinction between a prenasalization phase and an oral closure and release that follow it. While prenasalization is less often encountered in verbs than nouns for the reasons explained above, we conclude that it simply reflects affixation bleeding the otherwise expected process of nasal venting before a voiced stop, potentially applicable in both nouns (whether native or loanwords) and verbs.

\subsection{Glottal transparency}

Maxakalí is a language that permits leftward nasal harmony when originating with a stressed nasal vowel, though this harmony is blocked by voiceless obstruents intervening, as is well-known within the typology of blocking in nasal harmony (WALKER, 2003). Interesting, therefore, is the question of whether the relevant blocking factor interacts with sonority and with supraglottal articulation. The phonological characterization of harmony therefore highly depends on whether the formalization of blocking vs transparency is in terms of pure definition as fricative or stop, or whether glottals are treated as more sonorous (as in LOMBARDI, 2001) - and hence permissive of nasalization, or simply irrelevant as they contain no supralaryngeal node (as in SAGEY 1986). Nonetheless, descriptive issues remain about the nasalization of glottals in Maxakalí, largely because of the difficulty of perceiving it auditorally. The use of nasal measurements is thus quite informative, particularly in regards to the contrast between the glottal fricative and the glottal stop. 
The first word to be presented in this connection, the long form [teã' 'ã̃ ] 'slug' is of importance because it demonstrates nasal transparency, originating with the stressed nasal vowel, and spreading leftwards across a glottal stop.

FIGURE $7-$ [tcã' 'Tã $]$

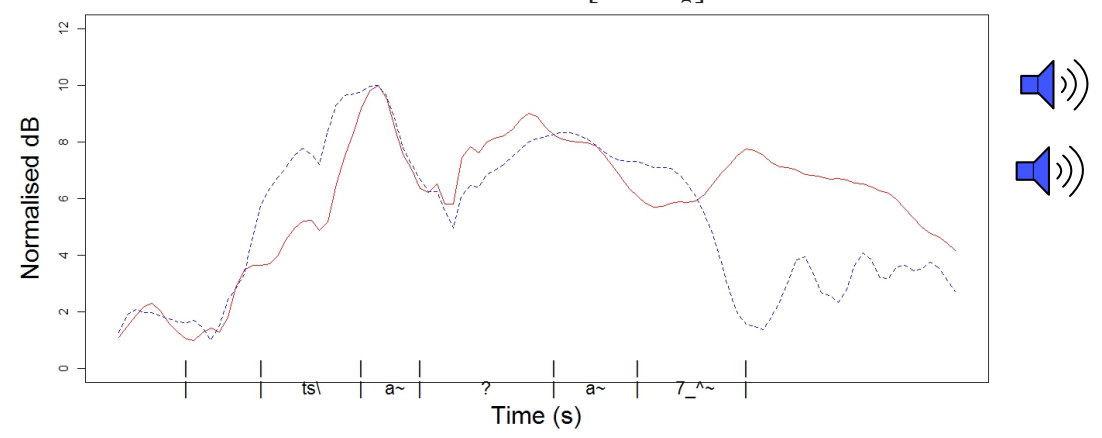

This token, produced by adult female speaker SM, shows that while there is no nasalization during the word-initial voiceless affricate, the velum is lowered immediately when the first vowel begins, and continues all the way to the end of the word, remaining steady throughout the glottal stop and onto the second vowel, and only decreasing during the final offglide. The presence of nasalization in this word - both in the glottal and indeed in the first vowel itself - is of importance in descriptive terms because this word has been previously described as lacking nasalization on the initial vowel (POPOVICH; POPOVICH, 2005).

The second token is one with the glottal fricative, [nã'hã̃] 'annato', as produced by elderly female speaker MSM.

FIGURE 8 - [nã'hãõ̃]

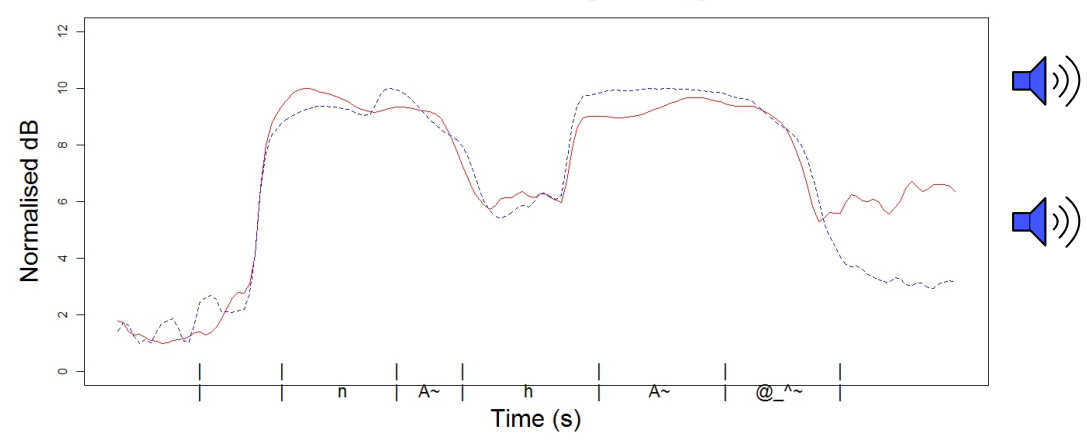


This example, like the one above, demonstrates nasality both in the first vowel and in the glottal fricative that intervenes between the first and second vowel. In fact, this word demonstrates nasality entirely throughout, providing a canonical example of a fully harmonized word. We may thus conclude that although they are distributionally more restricted in the language $([\mathrm{h}]$ occuring only in onset, and the glottal stop occuring only intervocalically), and while not phonologically contrastive in the language, glottal consonants in Maxakalí undergo nasalization in the same environments as voiced onsets.

The relevance of glottal transparency in Maxakalí takes on further importance given its interaction with the morphophonology of what are called long and short forms in the language. In its most compact description, long forms are found as the citation form of nouns, and found when they occur postverbally, e.g. [mã'hã x̃] 'fish'. However, in compounds, suffixed forms, and when occurring preverbally, such nouns occur in their short form, e.g. [mã $\tilde{x}^{\prime}$ piuㅣ] 'fish catch'. There is debate as to which form of the noun is underying and which is derived; Araújo (2000), among others, argues that the long form is underlying, whereas Wetzels (2009) ${ }^{3}$ and Silva (2016) argues that the short form is underlying. One of Silva's arguments is based on the identity of the two vowels in the long form and their interaction with allophonic environments. In Maxakalí, vowels show a different realization when they precede coronal consonants: /a, $\varepsilon, \mathrm{i}, \mathrm{o} / \rightarrow[\mathrm{a}, \mathfrak{\mathrm { x }}, \mathrm{I}, \mathrm{v}] /[\quad[+$ coronal $]$. Importantly, the pre-coronal allophone is maintained in both halves of the long form, even though the 'first' half is not directly before a coronal. Thus, the long form of /dãd/ 'annatto', as shown above, maintains this allophonic vowel quality in both halves [nã' hã̃̃], and not *[nã. 'hã̃̃], demonstrating that the allophony is copied over to the first vowel in the long form. This pattern is more clearly explained if the short form is underlying. However, it may still be possible to explain this in terms of the long form being underlying, provided a mechanism for harmony (and thus vowel identity) is in place. Confirmation of the transparency of glottals

\footnotetext{
${ }^{3}$ Although Wetzels' (2009) analysis considers that the short form is underlying, it relies in part on inaccurate data and affirmations from Araújo (2000) such as " [...] according to Araújo (2000), the glottal sound that occurs in the long forms, although it is usually realized as [h], alternates freely with [?]." There are not any cases of such variation in our data.
} 
for nasal harmony, therefore, indirectly bears consequences for analyses of harmony more generally in the language.

\subsection{Loanwords}

The distribution of nasality in loanwords is of great interest, as discussed in Wetzels (2009) and Silva \& Nevins (2015), particularly when it reflects a discrepancy in nasality of consonants between the source and donor language. In Maxakalí native vocabulary, syllables such as [na] and [dã] are banned: onset consonants cannot be nasal without the presence of a nasal vowel that follows. This predictable pairing of nasal onsets with nasal vowels has been reflected in an allophonic analysis of the two, whereby voiced stops are taken to be underlying and their nasal variant arises from predictable processes of spreading, and is enshrined in the orthographic system developed by Popovich \& Popovich (2005), which does not graphemically distinguish voiced stops from their nasal counterparts. However, the influx of Portuguese loanwords is leading to the emergence of oral voiced stops before nasal vowels, as with words such as [bã' $\varepsilon$ ə] (from Portuguese banheiro 'bathroom').

These divergences from the otherwise regular spreading of nasality within syllables found in Maxakalí are of course understandable in terms of the tradeoffs that arise in loanword phonology, whereby faithfulness to the identity of consonants in the source language play a role as well. Such a case arises in the adaptation of words such as laranja 'orange' in Portuguese, which are adapted as [ $\left.{ }^{\mathrm{n}} \mathrm{da} . \mathrm{d} \tilde{\mathrm{f}}\right]$ ]. As Maxakalí has no liquids in its native inventory (despite the name of the language, which remains an exonym), both the lateral and rhotic are adapted as [d]. Notably, this coronal onset resists onset nasalization.

FIGURE $9-\left[{ }^{\mathrm{n}} \mathrm{da}{ }^{\prime} \mathrm{d} \tilde{\mathrm{j}}\right]$

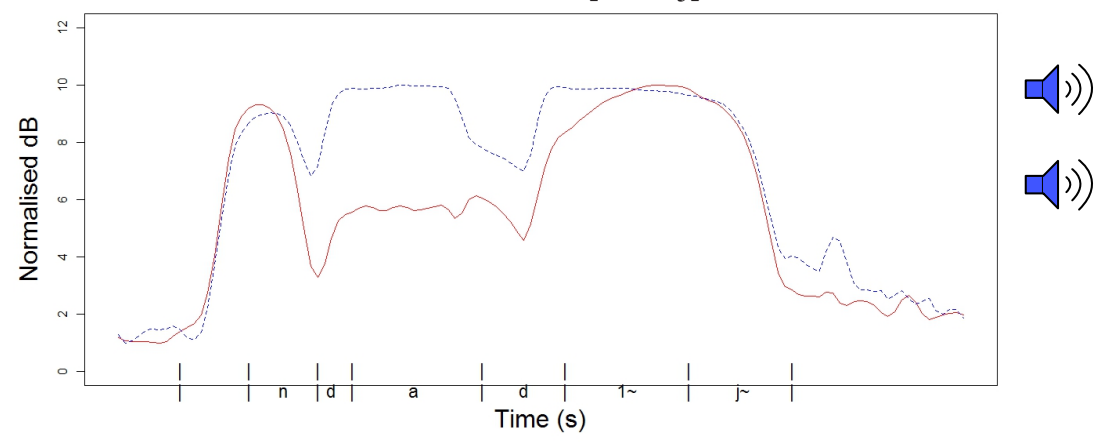


The recording, with adult male speaker RM exhibits prenasalization of the word-initial [d], of the same nature as that described in the subsection above. Of central interest to the present discussion is the predominately oral onset in the second syllable. While the final vowel and its coda are fully nasal, as shown by the solid intensity curve, its onset fails to undergo nasalization. This example therefore provides confirmation for a fully oral onset consonant preceding a nasal rime in Maxakalí, arguably an emerging consequence of the sometimes conflicting demands posed by loanword phonology.

As described in Wetzels (2009) and Silva \& Nevins (2015), on the other hand, occasionally loanwords do exhibit a distribution of nasality that goes far above and beyond what is present in the source form. The adaptation of the Brazilian soccer team Flamengo is of particular interest in this case. This item undergoes epenthesis between the initial labial consonant (adapted as voiceless [p] in Maxakalí) and the following coronal consonant. However, speakers show three possibilities of the realization of the source [1]. Some adapt the lateral as [n] as in [panãmãj], undergoing nasal spreading from the following nasal vowel. However, these fall into two subgroups: [pãnãmæ̃̃j] and [panãmæ̃̃j] where the difference between these two lies in the presence (the former) or absence (the latter) of further leftwards vowel harmony extending to the preceding vowel. These are shown below for speakers RM and IZM below:

FIGURE 10 - [pãnã' m̃̃̃̃]

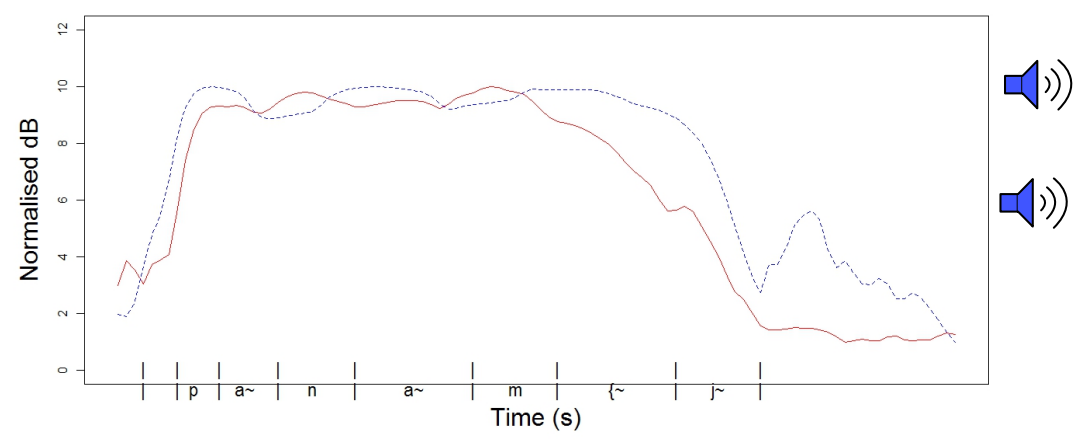


FIGURE $11-$ [panã' mæ̃̃j]

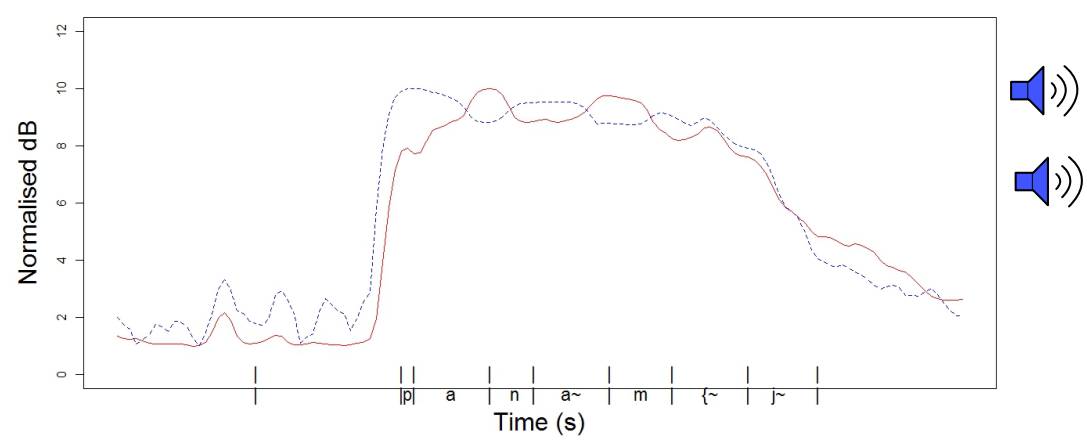

As can be seen from the solid intensity curves above, adult male speaker RM shows nasality from the first vowel of the word all the way until the end, with a gradual raising of the velum as nasality peters out. On the other hand, adult male speaker IZM only begins nasality in the final portion of the initial vowel, as coarticulatory anticipation of the following nasal onset, after which it extends all the way to the end of the word. From this instrumentally-informed comparison, we can conclude, in concert with the proposal of Silva \& Nevins (2015), based on purely auditory transcriptions that leftwards vowel-to-vowel harmony is a gradient phenomenon, even across an intervening nasal consonant.

Still others, in a solution to loanword phonology that remains within the native inventory (in eschewing [1]) but diverges from its

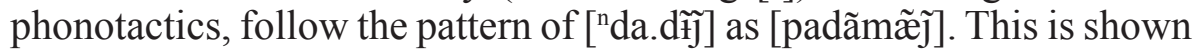
below for the young male speaker IM.

FIGURE 12 - [padã' mã̃]]

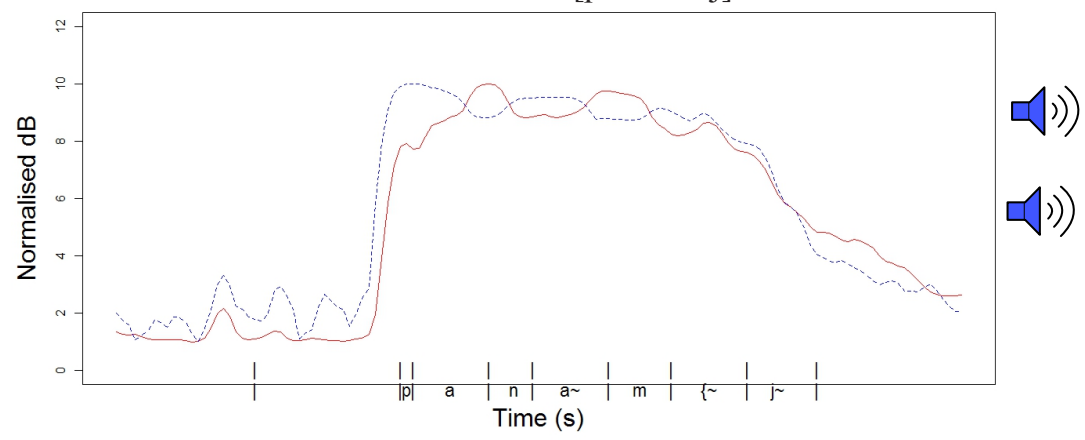


In this example, as shown by the solid intensity curve, velum lowering only occurs during the nasal vowel [ã] following the oral stop [d], and continues until the end as in the same relevant portion of the profile of this word as pronounced by RM above.

Summarizing this subsection, both words discussed here illustrate that Maxakalí loanwords allow an oral voiced stop to precede a nasal vowel, in contradiction to the otherwise entirely predictable allophonic distribution whereby nasal vowels must have nasal onsets (if the consonant is voiced). Given that such a pattern necessitates a revision of the overall picture of Maxakalí phonology (and potentially, down the road, its orthography), this makes all the more valuable a verification that indeed such consonants evade nasality, afforded by this instrumental method.

\subsection{Nasal spreading from the diminutive}

In this final subsection, we discuss one of the more languagespecific aspects of the distribution of nasality in this language, one resulting from the leftward spreading induced by the diminutive suffix [-nãy]. According to Campos (2009), this suffix induces nasal spreading in verbs, but not nouns. This is shown for [kukæçnãy] 'dog-dim.', by the adult male speaker PM, below.

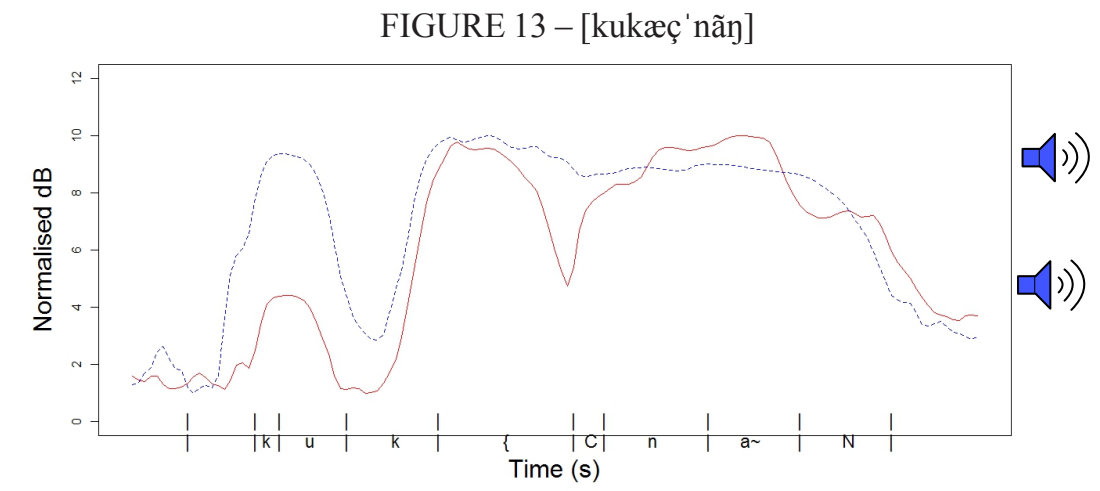

As shown by the red intensity curve, nasality is not part of the production of the root, and obtains only during the suffix-initial nasal consonant, thereby demonstrating that, for nouns such as this one, the diminutive does not induce nasalization. 
In verbs, however, as discussed by Campos (2009), the diminutive causes leftward nasalization of the root-final consonant and, in turn, the vowel that precedes it. This can be shown in the following pair of recordings with adult male speaker IZM below. The first curve is for [pi'tiurij] 'heavy', which has no nasality. The second is for its diminutivized form 'heavy-dim.', which shows nasalization of the entire rime of the root.

\section{FIGURE $14-$ [pi'tíuij]}

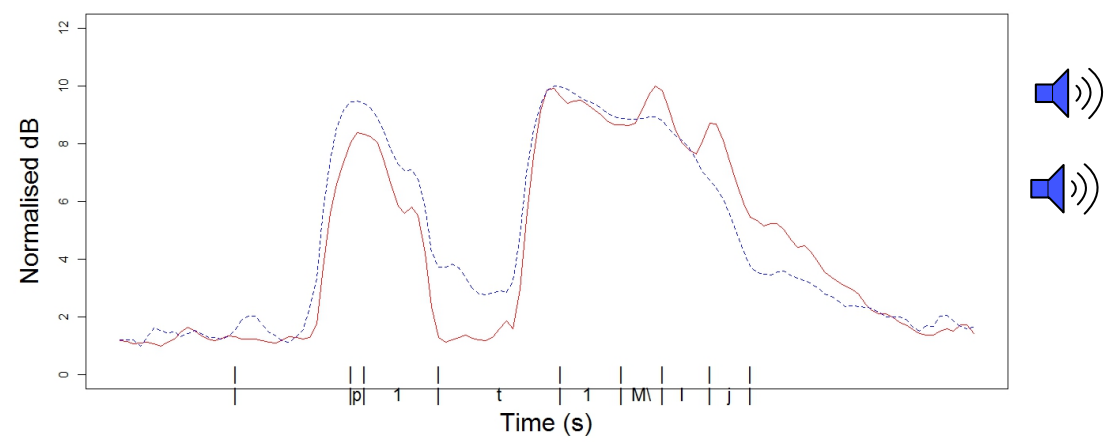

In the figure above, the nasal curve does not surpass that of the

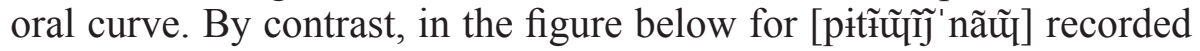
with IZM as well, nasality clearly obtains from the root-final vowel onwards:

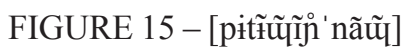

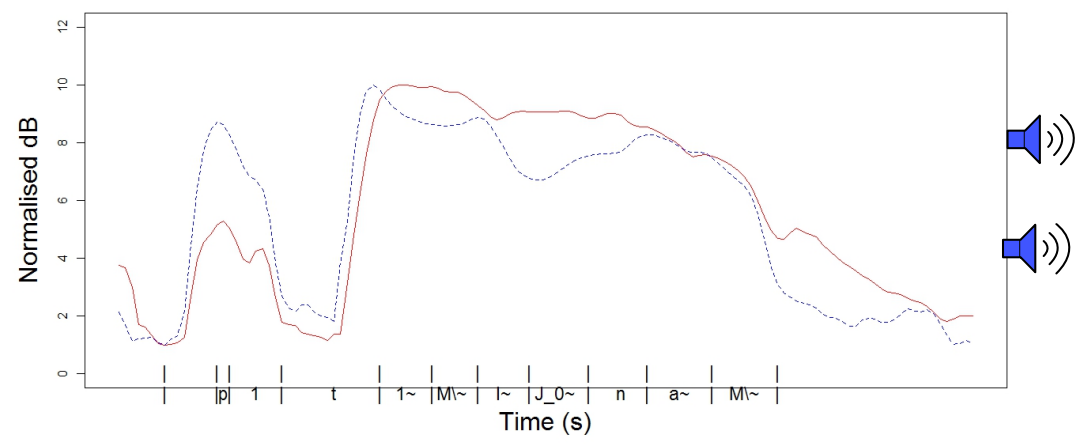


This latter example, 'heavy-dim.', based on a verb, shows a clear effect of morphologically-induced nasalization into the base. Its morphological conditioning is evident in the fact that in a nearly parallel noun, [pitiuıı' nãũ] 'bird/birdy', no nasalization obtains. Of course, this is a 'frozen' diminutive, based on a root that is no longer synchronically present, ${ }^{4}$ but it also serves to show that the segmental content of the final syllable [nãy] is not enough on its own to induce nasalization in an otherwise identical sequence to its left.

Finally, it should be said that diminutive nasal spreading in verbs itself shows interspeaker variation. The form [ki' bik] 'bad' can undergo complete nasalization, as shown for speaker IM below:

FIGURE 16 - [kт̃mัก๊ 'nãỹ]

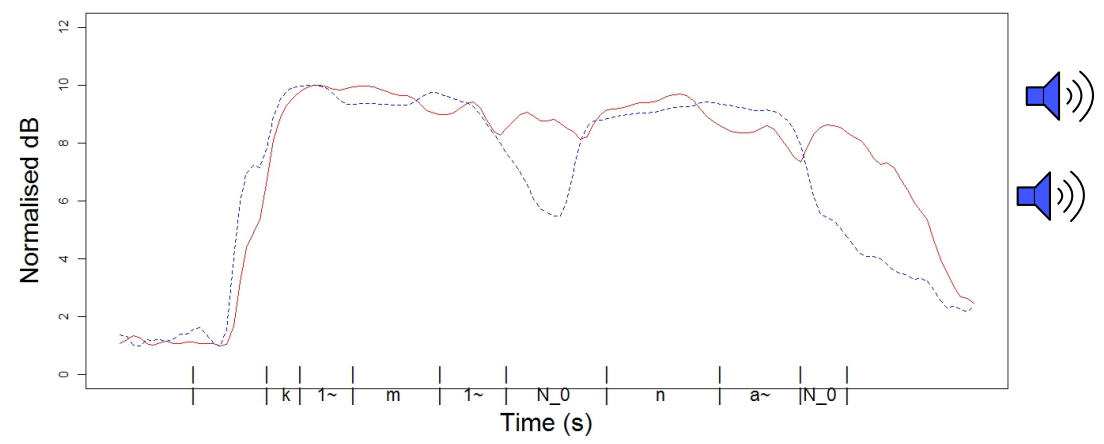

This form, given the base [ki'bik] 'bad', has undergone leftward nasalization in the root-final coda, subsequently spreading to the entire syllable, and further leftward in nasal harmony, halted only by the word-intial voiceless stop. On the other hand, speaker MSM shows no nasalization at all of the root. Note that this token includes an inflectional $3^{\text {rd }}$ person prefix [ [̃] , which is an inherently nasal vowel.

\footnotetext{
${ }^{4}$ The plausibility of a root meaning 'bird' inside a frozen diminutive, interestingly, gains support from the recent tentative reconstruction of 'feather' and 'bird' in ProtoMacro-Jê as * prr(C) by Nikulin (2015, p.293), which would then undergo sound change to Maxakali *[pitij], following the steps posited in Silva (2016).
} 
FIGURE 17 - [̊̃kibik' nãũu]

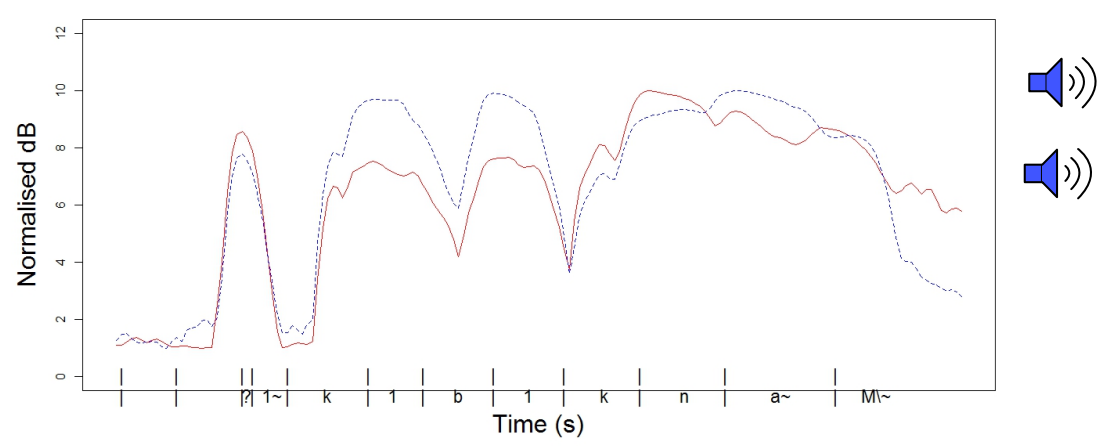

In this token, the oral intensity curve dominates the nasal out the root, but the velum does lower during the production of the suffix.

Finally, we show that the pattern of nasalization induced by the diminutive suffix with monosyllabic roots such as [douk ' straight' can lead to a sequence of oral voiced stop followed by nasal vowel, again in apparent contradiction of the otherwise exceptionless phonotactic that nasal vowels induce onset nasalization of voiced stops.

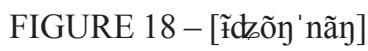

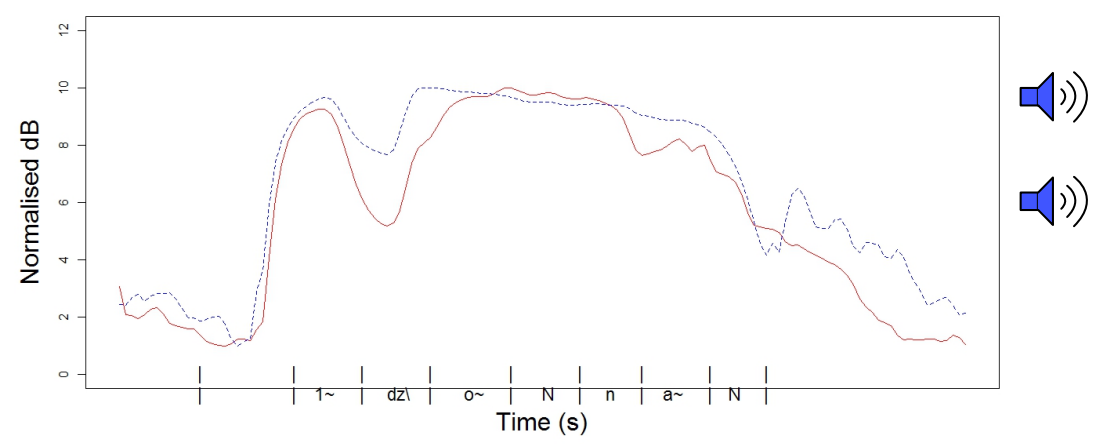

The gradient patterning of nasalization found with verbs but not nouns, and with exceptional and optional behavior, can therefore lead to another source for emerging non-allophonic distribution of voiced stops vs. their nasal counterparts.

To summarize the empirical situation overall, therefore, nasalization in verbs, while variable in its application and extent, can 
obtain, as confirmed by earbud microphony, while nasalization in nouns was never found. This is a valuable new descriptive contribution that goes beyond impressionistic descriptions of nasalization. The availability of earbud microphony for field recordings enables us to study phenomena such as this with a wide range of speakers, across ages and genders, which allows one to investigate variable phenomenon with a large sample size and address ethnosociolinguistic questions. Recordings with a diverse demographic range of participants would not have been as straightforward if one needed to bring speakers far from their homes to a laboratory and/ or use unfamiliar equipment.

\section{Future directions}

In this article, we have shown how instrumental measurements of nasal airflow can break the stalemate that can arise with decriptive claims that necessitate potential revisions from one's theoretical comfort zone. With earbud microphones, segmental transcription, and subsequent execution of scripts, questions such as prenasalization of voiced stops, spontaneous nasalization of initial vowels, failure of onset nasalization, laryngeal transparency to nasal harmony, and morphophonologicallyconditioned restrictions on nasal spreading can all be addressed with visual clarity.

As these five aspects of nasalization across consonants, vowels, and their interaction with processes such as prenasalization, nasal harmony, and loanword adaptation are widespread across South American languages (and beyond), the promise of this technique for such crosslinguistic investigations is clear. In some cases, one can confirm earlier auditory impressions, in others apparently divergent descriptions or analyses do turn out to boil down to interspeaker variation, and in others, the description or the researcher can reflect on potential reasons the auditory impressions diverge from the representations obtained by recording and normalizing oral and nasal tracks. Either way, more data and metadata accompanying them are added to the empirical base.

Going beyond these considerations, we also view the potential of earbud microphony and its nearly immediate ability to generate a visual representation of the nasal profile of a word as yielding possibilities for experimental linguistics to show increased integration with language pedagogy. Showing native speakers and in particular, those concerned with indigenous education and orthography reform the immediate 
representation of nasality has clear potential for more close integration between educational technology and development of pedagogical materials within the village context. As an example, we can cite the fact that many Maxakalí often omit the orthographic tilde when writing. This diacritic serves as an indicator of nasalization and its absence can lead to potential confusion in reading. Its omission - which could be influenced by the fact that is impossible to place tilde over the graphemes $e, u, i$ using a Portuguese keyboard layout, and so users must use $<\hat{e}, \hat{u}, \hat{i}>$, the comfortability of typing which may lead to_questioning how often they are needed - may be because some instances are highly predictable thanks to nasal harmony from the stressed vowel or by other means.

Nasal earbuds are easy to use and lend themselves to excellent possibilities for student projects at the beginning research level as well as for younger or technologically-savvy members of the indigenous community to be involved hands-on with new ways of visualizing the sound patterns of their language. We have shown that they can be used for consonantal and vocalic nasality phenomena, loanword phonology, variable phenomena, and morphologically-conditioned patterns, and in making our dataset available with the textgrids and a pointer to the scripts, they have the potential to form part of 'visual dictionaries' showing what nasality does within given sets of recurrent word patterns.

\section{Acknowledgements}

We would like to thank Martin Kohlberger and Jesse Stewart for help with numerous technical aspects of applying this research method. We would also like to thank Leo Wetzels and the three anonymous reviewers for their thorough reading and insightful suggestions that led to improving this paper. Finally, we acknowledge the Maxakalí people from Aldeia Verde for their contribution and collaboration.

\section{References}

ARAÚJO, Gabriel Antunes. Fonologia e morfologia da língua Maxakalí. 2000. Thesis (Masters') - Instituto de Estudos da Linguagem, Universidade Estadual de Campinas, 2000. 
AUDIBERT, Nicolas; AMELOT, Angélique. Comparison of nasalance measurements from accelerometers and microphones and preliminary development of novel features. In: INTERSPEECH 2011 - ANNUAL CONFERENCE OF THE INTERNATIONAL SPEECH COMMUNICATION ASSOCIATION, $12^{\text {th }}, 2011$, Florence. Proceedings... Florence: International Speech Communication Association, 2011. p. 2825-2828.

CAMPOS, Carlo Sandro. Morfofonêmica e Morfossintaxe do Maxakalí. 2009. Dissertation (Doctoral) - Faculdade de Letras, Universidade Federal de Minas Gerais, Belo Horizonte, 2009.

CHEN, Marilyn. Acoustic Correlates of Nasality in Speech. 1996. Dissertation (PhD) - MIT, Cambridge, MA, 1996.

DEMOLIN, D. The influence of aerodynamic constraints on the shape and the dynamics of phonological systems. In: INTERNATIONAL CONGRESS OF PHONETIC SCIENCES, XVII., 2011, Hong Kong. Proceedings... Hong Kong: City University of Hong Kong, 2011. p. 60-63.

FLETCHER, Samuel G.; SOOUDI, IRADJ; FROST, Sharon D. Quantitative and graphic analysis of prosthetic treatment for 'nasalance' in speech. The Journal of Prosthetic Dentistry, Elsevier, v. 32, p. $284-$ 291, 1974.

FUJIMURA, Osamu. Syllable structure of Kaingang: A C/D Model Interpretation. Presented at TCP, July 2010.

GUDSCHINSKY, Sarah; POPOVICH, Harold; POPOVICH, Frances. Native Reaction and Phonetic Similarity in Maxakalí Phonology. Language, Washington, v. 46, p. 77-88, 1970.

IVERSON, G. K.; SALMONS, J. C. Mixtec prenasalization as hypervoicing. International Journal of American Linguistics, Chicago University Press, v. 62, p. 165-175, 1996.

LOMBARDI, Linda. Why place and voice are different: constraintspecific alternations in Optimality Theory. In: . (Ed.). Segmental Phonology in Optimality Theory. Cambridge University Press, 2001. p. 13-45. 
MONTAGU, Julie; AMELOT, Angélique. Comparaison des apports de différents méthodes d'enregistrement de la nasalité: étude préliminaire. In: RENCONTRE JEUNES CHERCHEURS, 2005, Toulouse. Toulouse: Université Paul Sabatier, 2005. p. 17-21.

NIKULIN, Andrey. Apofonia e o sistema vocálico do Proto-Jê Meridional: contribuição para estudos comparativos das línguas Jê. Revista Brasileira de Linguística Antropológica, Brasília, UnB, v. 7, n. 2, p. 275-306, 2015.

PIÑEROS, Carlos Eduardo. Accounting for the instability of Palenquero voiced stops. Língua, Elsevier, v. 113, p. 1185-1222, 2003.

POPOVICH, H.; POPOVICH, F. Dicionário Maxacali-Português com Glossário Português-Maxacali. Cuiabá: SIL, 2005.

RODRIGUES, Aryon. Nasalização e fronteira de palavra em Maxakalí. In: ENCONTRO NACIONAL DE LINGUISTICA, V., 1981, Rio de Janeiro. Anais... Rio de Janeiro: Pontifícia Universidade Católica, 1981. p. 305-311.

RODRIGUES, Aryon. Silêncio, pausa, e nasalização. In: ENCONTRO NACIONAL DE LINGUISTICA, VIII., 1986, Rio de Janeiro. Anais... Rio de Janeiro: Pontifícia Universidade Católica, 1986. p. 153-158.

SAGEY, E. The representation of features and relations in non-linear phonology. 1986. Dissertation (Doctoral) - MIT, 1986.

SÂNDALO, F.; ABAURRE, M. B. Orality spreading in Pirahã. Liames, Campinas, Unicamp, v. 10, p. 7-19, 2010.

SHOSTED, R. Vowel context as a condition for nasal coda emergence: aerodynamic evidence. Journal of the International Phonetic Association, Cambridge University Press, v. 36, p. 39-58, 2006.

SILVA, Mário André Coelho. A coda consonantal em Maxakalí. 2015. Thesis (Masters') - Instituto de Estudos da Linguagem, Universidade Estadual de Campinas, Campinas, 2015.

SILVA, Mário André Coelho. Um novo olhar sobre formas longas e curtas em nomes no Maxakalí. In: ENCONTRO MACRO-JÊ, VIII., 2016, Londrina. Paper presented. 
SILVA, Mário André Coelho; NEVINS, Andrew Ira. Domain-based preservation of nasality in Maxakalí loanwords. In: MANCHESTER PHONONOLOGY MEETING (MFM), 23 ${ }^{\text {rd }}$, 2015, Manchester. Paper presented.

STEWART, J.; KOHLBERGER, M. Earbuds: A method for measuring nasality in the field. Journal of Language Documentation and Conservation, University of Hawai'I, v. 11, p. 49-80, 2017.

STYLER, Will. On the Acoustical and Perceptual Features of Vowel Nasality. 2015. Dissertation (PhD) - University of Colorado, Boulder, 2015

WALKER, Rachel. Reinterpreting transparency in nasal harmony. In: VAN DE WEIJER J.; VAN HEUVEN, V.; VAN DER HULST H. (Ed.). The Phonological Spectrum Vol 1: Segmental Structure. Amsterdam; Philadelphia: John Benjamins Publishing, 2003. p.37-72.

WETZELS, Leo. Prevowels in Maxacali: Where They Come From. Boletim da Associação Brasileira de Lingüística, Belo Horizonte, v. 14, p. 39-63, 1993.

WETZELS, Leo. Nasal Harmony and the Representation of Nasality in Maxacali: Evidence from Portuguese Loans. In: CALABRESE, A.; WETZELS, W. L. (Ed.). Loan Phonology. Amsterdam: John Benjamins Publishing, 2009. p. 241-270.

WETZELS, Leo; NEVINS, Andrew Ira. Prenasalized vs Postoralized Stops: Diverse Types of Enhancement. Manuscript, 2016.

WETZELS, Leo; SLUYTERS, Willebrord Formação de raiz, formação de glide e 'decrowding' fonético em Maxacalí. In: WETZELS, L. (Ed.). Estudos Fonológicos das Línguas Indígenas Brasileiras. Rio de Janeiro: Editora UFRJ, 1995. p. 103-149 


\section{APPENDIX A}

\section{Recorded Wordlist and Translation}

\begin{tabular}{|c|c|}
\hline Maxakalí & English \\
\hline Ãnenep & Andrew \\
\hline ãxok & sugar (< Port. açúcar) \\
\hline ãyuhuk & non-indigenous \\
\hline gahap & bottle (< Port. garrafa) \\
\hline hitũmnãg & happy-DIM \\
\hline hitup & happy, healthy \\
\hline Homet & Roberto (male name) \\
\hline Hoyet & Rogério (male name) \\
\hline$\tilde{I} \tilde{a}$ & Ian \\
\hline ixõg Ĩxõg & bird \\
\hline ixpot & spur (< Port. espora) \\
\hline ĩypex & mirror $(<$ Port. espelho) \\
\hline kokexnãg & dog-DIM \\
\hline Kõyãyiy & Cunhadinho (male nickname) \\
\hline kũĩn & stripped \\
\hline kũĩnnãg & stripped-DIM \\
\hline kumuk & bad \\
\hline kumuknãg kũmũgnãg & bad-DIM \\
\hline kũnõhõn & cockroach \\
\hline mãhãm & fish \\
\hline mahap & turn around \\
\hline mai & good \\
\hline mainãg mãĩnnãg & good-DIM \\
\hline Mãxakani & Maxakalí (exonym) \\
\hline mayix & bowl (< Port. vasilha) \\
\hline mĩkax hã & with the knife (lit. knife INSTR) \\
\hline mĩnkup & sugarcane \\
\hline mot & ball (< Port. bola) \\
\hline mot mõyõn & play football \\
\hline
\end{tabular}




\begin{tabular}{|c|c|}
\hline $\operatorname{mox}$ & cow, ox (< Port. boi) \\
\hline mũnũytut & cow, ox \\
\hline nagnãg & dry-DIM \\
\hline nãhãn & annatto \\
\hline nak & dry \\
\hline Nanaĩn & Ladainha (town name) \\
\hline nanuy & orange ( $<$ Port. laranja) \\
\hline nax $\sim$ naix & pot \\
\hline Pãnãmẽy Panãmẽy & Flamengo (football team) \\
\hline penãhã & see, watch \\
\hline ponognãg & white-DIM \\
\hline ponok & white \\
\hline putõõy & mud, clay \\
\hline putux & heavy \\
\hline putuxnãg & bird \\
\hline putũynãg & heavy-DIM \\
\hline Tẽãn & Ateanderson (male name) \\
\hline Tikmũũn & Maxakalí (endonym) \\
\hline tonok & step \\
\hline tonoknãg & step-DIM \\
\hline xããm & snail \\
\hline xẽẽnãg & true \\
\hline xuta & red \\
\hline xutãnnãg & red-DIM \\
\hline Yaet & Isael (male name) \\
\hline yĩmamnãg & turn around-DIM \\
\hline yĩmap & turn around \\
\hline Yitmã & Gilmar (male name) \\
\hline yognãg & straight-DIM \\
\hline yok & straight \\
\hline
\end{tabular}


1042 Revista de Estudos da Linguagem, Belo Horizonte, v.25, n.3, p. 1011-1042, 2017

\section{APPENDIX B}

X-SAMPA values and IPA correspondence

\begin{tabular}{|c|c|}
\hline X-SAMPA & IPA \\
\hline $\mathrm{i}$ & $\mathrm{i}$ \\
\hline I & I \\
\hline\{ & $æ$ \\
\hline a & $\mathrm{a}$ \\
\hline $\mathrm{A}$ & $a$ \\
\hline o & o \\
\hline $\mathrm{u}$ & $\mathrm{u}$ \\
\hline $\mathrm{U}$ & U \\
\hline $7 \_\wedge$ & $\gamma$ \\
\hline$a_{-} \wedge$ & 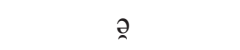 \\
\hline $\mathrm{p}$ & $\mathrm{p}$ \\
\hline $\mathrm{t}$ & $\mathrm{t}$ \\
\hline ts $\backslash$ & t6 \\
\hline $\mathrm{k}$ & $\mathrm{k}$ \\
\hline$?$ & $?$ \\
\hline $\mathrm{b}$ & $\mathrm{b}$ \\
\hline d & $\mathrm{d}$ \\
\hline $\mathrm{dz} \backslash$ & d \\
\hline $\mathrm{g}$ & $\mathrm{g}$ \\
\hline $\mathrm{m}$ & $\mathrm{m}$ \\
\hline $\mathrm{n}$ & $\mathrm{n}$ \\
\hline $\mathrm{J}$ & $\mathrm{n}$ \\
\hline $\mathrm{N}$ & $\eta$ \\
\hline $\mathrm{h}$ & $\mathrm{h}$ \\
\hline $\mathrm{C}$ & ç \\
\hline $\mathrm{j}$ & $\mathrm{j}$ \\
\hline $\mathrm{M} \backslash$ & щ \\
\hline$\sim($ e.g.: $\mathrm{a} \sim)$ & nasality (e.g.: ã) \\
\hline $0($ e.g.: n_0 $)$ & devoicing (e.g.: n \\
\hline
\end{tabular}

